\section{The ethical problems of genetic engineering of human beings}

Willem Jacobus Eijk, 313 pages, Urbe, 1990, 25.00 DF. Available from the author at: Seminarie Rolduc, 6464 EP, Kerkrade, Holland

W J Eijk is a Catholic Christian philosopher and he submitted this thesis for the degree of licence in theology in Rome. It is written in rather stilted English and this does detract from the general flow of the text. The references quoted are in various languages, including English, German, Italian, French, Greek and Latin, but a source of translation for some of the Latin references is given.

Two aspects of genetic engineering are considered. Firstly, molecular genetic engineering or DNA recombinant technology, ie modifying cloned genes and returning them to living cells; and secondly cellular genetic engineering or non-molecular ways of altering the genetic material such as cellular fusion and transplantation of complete nuclei.

The first part of the thesis provides a brief explanation of the basic scientific principles involved. In the section on methods of transmission of hereditary diseases, statements which have been oversimplified lead to inaccuracies: for example, ' $\mathrm{X}$-linked recessive gene disorders occur exclusively in males'. Techniques of molecular and cellular genetic engineering are described briefly, followed by a concise and clear statement on the list of conditions which must be fulfilled if somatic gene therapy of hereditary diseases is to be successful. The last part of the scientific introduction reviews methods of genetic engineering of germ line cells and their application in both the fertilised ovum and in the gametes.

The main part of the thesis addresses two questions. Firstly, is it morally acceptable (and compatible with the philosophy of St Thomas Aquinas) to intervene in human beings on such a fundamental level? The views of various philosophers over the ages are considered, and Eijk discusses the 'creation command' ('God said ... "Be fruitful, multiply, fill the earth and conquer it" ...') which some authors interpret as a theological sanctioning of genetic engineering. He concludes that one cannot entirely reject man's intervention in human DNA on theological or philosophical grounds, because genetic interventions in human DNA done for therapeutic reasons are intrinsically good, as the faithful have always regarded it as their duty to combat evil (including disease). The question then evolves to become in what situations is modification of human DNA allowed?'.

This section is the one in which the influence of the teachings of the Catholic Church becomes most apparent, particularly because the only acceptable method of procreation is via the conjugal act. Molecular genetic engineering of somatic cells and their subsequent re-introduction into the body (for the treatment of disease) is a form of autotransplantation and therefore acceptable. Germline therapy in fertilised human ova is regarded as unacceptable, however, because it is connected with in vitro fertilisation. Embryo experiments lacking any possible therapeutic benefit for that embryo are found to be morally objectionable because of the respect owed to the human individual from the moment of conception. For the same reason, the cloning of a series of identical embryos in order for some to be sacrificed for the diagnosis of gene defects is unacceptable. In addition, the view that the fertilised egg is ensouled from the moment of conception means that the author concludes that genetic engineering in gametes rather than fertilised ova would be preferred, on condition that fertilisation would not be by artificial means.

For Catholics grappling with the various complex issues discussed in this thesis, the extensive references and consideration of statements from the Vatican and the Bible will be useful. For non-Catholics involved in genetic engineering, however, the book will be interesting but rather restricted in its use, because those aspects of genetion engineering which are totally unacceptable to the Catholic Churche (for example IVF and cloning) are not discussed in much detail, and other moral viewpoints in these complex fields are not really considered.

FRANCES A FLINTER Division of Medical and Molecular Genetics, UMDS, Guy's Hospital

Naming the silences: God, medicine, and the problems of suffering

Stanley Hauerwas, 154 pages + xiv, Grand Rapids, Michigan, 1990, William B Eerdmans Publishing Company, $\$ 9.95$

This is a book by a professor of theological ethics which sets out to look at the problem of suffering, especially the suffering of children with leukaemia, from a theological point of view. In doing so, however, it also examines what is going on in the minds of the patients and the attitudes and actions of medical and nursing staff. The book can, therefore, be read at two levels, the theological and the practical. 
The reviewer was disappointed in the theological discussion but found valuable insights in the realm of medical practice.

The author is concerned about what he calls 'the silences' which develop in the course of fatal illness, and particularly the conspiracy of silence by which he sees the medical staff protecting themselves by keeping the interaction with patients as brief as possible to avoid becoming too involved. He sees the constant activity and striving for cure as 'a messy way to hide the silences'. He quotes evidence that the children in the oncology ward know far more about their condition and the fact that they are dying than either their parents or the medical staff realise. And because the childen are unable to discuss their fears, they die 'terribly alone'.

Running through the book is the question which particularly concerns the author: Why does a good and allpowerful God allow us to experience pain and suffering? The author is honest enough to conclude that he can find no satisfactory answer to this dilemma. 'The suffering of a child is pointless.' All we can gain from our suffering is a sense of compassion for one another's hurt. 'We are all sitting on a mourner's bench that is longer than we imagined.'

The author admits that up to approximately 300 years ago theodicy was not seen as a problem. It is only since the seventeenth century that it has been felt necessary to justify the ways of God in the light of the existence of evil. Unfortunately, he does not follow up that clue. It might have led to the classic two-world perspective of the New Testament, that views the next life as more important than this one, and understands life here as essentially preparation and training for life hereafter. Nor does the author take into account the inscrutability of God's ways - the thought that, as the prophet Isaiah put it, God's ways are higher than our ways and his thoughts than our thoughts. It was this that comforted Sir James Young Simpson, the famous Edinburgh obstetrician, as he stood at the graveside of his seventeen-year-old daughter, and recalled the words of Jesus: 'What I am doing you do not know now, but afterward you will understand.'

DAVID SHORT Cardiac Department, Aberdeen Royal Infirmary

\section{Ethical dilemmas in paediatrics - a case- study approach}

EN Forman and R E Ladd, 142 pages, New York, 1991, Springer-Verlag, DM 64 hard cover

This is a very readable book which covers the wide range of ethical dilemmas found in the practice of paediatrics. The book is divided into six major parts. The parts cover:

Who has the chance in decisionmaking?

How much and when should the truth be told?

Deciding on the limits of treatment.

The problem of child volunteers in research.

Conflicts of costs and loyalties.

The special problems of treating adolescents.

Each part of the book contains chapters which start with a brief case-history and some discussion questions which arise from the report. At the end of each of the six parts of the book, there are further brief case-reports and discussion questions. These combinations allow both in-depth discussion and generous width of subject matter.

Apart from excellent accessibility of the layout of the chapters and the wealth of ideas, the style of the discussion makes nearly compulsive reading. It is probably as a result of the interaction of the authors, who come from the differing backgrounds of paediatrics and philosophy, that the reasoning in the discussions seems both sensitive to the practical issues and sensible in the level of argument.

As in all good books there are some problems. It would be impossible to discuss medical ethics without considering the legal aspects. For readers outside the United States, some of the details of the legal side may appear redundant to their needs. However, I found it a stimulus to try to discover how the laws in the United Kingdom differed from those described. The ideal would be a British edition of this book, with a commentary on how the laws are different. Maybe this will have to wait until the book proves as successful as it promises to be, or until European laws related to medical ethics are harmonised within the member states. One particularly fascinating aspect, for areas from within the National Health Service in the United Kingdom, is the dimension of the private health service in the United States. A whole section on Considering Costs (chapter 20) exposes some dilemmas of conscience and loyalty which most British doctors have been spared. The whole area of conflict between doing the very best for the individual child within the system of trying to run an economical business, or in trying to avoid being penalised by health maintenance organisations, should send a timely shudder down the spines of those of us who appear to be on the brink of falling into the same pit.

I am sure this book will be used by many of us whose task is to help both undergradutes and postgraduates in the health professions to discover the importance of medical ethics, particularly related to children. It is an excellent source of both case material and summaries of balanced arguments. The bibliography and glossary are also very useful. No paediatric library will be complete without this book.

GRAHAM CLAYDEN, MD, FRCP, Honorary Consultant Paediatrician, St Thomas's Hospital, London.

\section{New harvest - transplanting body parts and reaping the benefits}

Edited by C Don Keyes in collaboration with Walter Wiest, xiii + 229 pages, Clifton, New Jersey, 1991,

The Humana Press, $\$ 34.50$ export

The term 'harvesting' has been felt by some to be unfortunate or objectionable in the context of human organ procurement, so to present a volume on the subject under the title New harvest might appear to be to take sides. Sides are taken, I think, but uncomfortably, for two reasons.

The first concerns the too-evident apologetics in much of this collection. It is useful to assemble the views of clinicians, theologians, lawyers and philosophers in a single volume, but the asociated danger is that too much ground is covered too scantily, and that the contributors are inclined to assert their own views without substantial defence. Sometimes this leads to glib superficiality, as in: 'The American sense of altruism and compassion for 